\title{
Alternatif Pemberantasan Buta Aksara Bagi Kaum Perempuan Berbasis Masjid
}

\author{
By: Rodiyah*
}

\begin{abstract}
Literacy is a problem for various developing countries and among people who are still experiencing illiteracy are women, various strategies and theories used to eradicate literacy among the community. The author described an alternative to literacy eradication for mosque-based women using qualitative methods with a sociological approach. in this research it was found that the stronger the motivation and means of gathering such as mosques, the more opportunities for women to hone their abilities, especially in the field of literacy, would be more open.
\end{abstract}

Keywords : Literacy, Mosque-Based

\section{PENDAHULUAN}

Pembangunan nasional memerlukan sumber daya manusia yang berkualitas. Hal ini menuntut semua warga masyarakat untuk memiliki kemampuan yang sangat mendasar yaitu kemampuan keaksaraan (membaca, menulis, berhitung dan berkomunikasi dalam bahasa Indonesia). Tujuan pembangunan nasional Indonesia dalam melakukan pembangunan sumber daya manusia yang berkualitas merujuk kepada United Nation Development Program (UNDP). UNDP menetapkan kemajuan suatu negara dapat ditentukan oleh tiga indikator indeks pembangunan manusia, yaitu indeks pendidikan, indeks kesehatan, dan indeks perekonomian (UNDP), Indikator indeks pendidikan merupakan hal yang sangat penting sekali dalam mewujudkan pembangunan manusia yang berkualitas, ketika masyarakat memiliki tingkat pendidikan yang tinggi. maka indeks kesehatan dan indeks perekonomiannya juga akan meningkat. ${ }^{1}$
Sedangkan menurut Badan Pusat Statistik, Pusat Data dan Kebudayaan Kementerian Pendidikan dan Kebudayaan yang dirilis oleh tempo.com mengungkap fakta yang cukup mencengangkan. Sebanyak 2,07 persen atau sekitar 3,4 juta dari penduduk Indonesia ternyata masih buta huruf. Direktur Pendidikan Anak Usia Dini dan Pendidikan Masyarakat Kementerian Pendidikan dan Kebudayaan Harris Iskandar mengatakan dari jumlah tersebut, sekitar dua sepertiganya adalah perempuan. "Dari hasil tersebut memang yang lebih banyak mengalami buta aksaranya kaum perempuan," kata dia di kantor Kemendikbud, Rabu, 6 September $2017 .^{2}$

\section{PEMBAHASAN}

Masalah buta aksara adalah masalah dunia. Bahkan UNESCO melalui Deklarasi Dakkar 2013 telah mengdeklarasikan bahwa masalah tuna aksara adalah masalah dunia. Panyandang 
buta aksara terbanyak berada di dunia ketiga atau di negara berkembang. Indonesia termasuk katagori negara berkembang. Dengan demikian Indonesia harus bertanggung jawab untuk menuntaskan penduduknya yang masih terpapar buta aksara. Penyandang buta aksara akan berkorelasi dengan kualitas sumberdaya manusia. Indeks pengembangan Sumber daya Manusia (Human Development Indexs). Salah satu indikator HDI adalah kemampuan dalam pendidikan. ${ }^{3}$

Melihat hal tersebut maka dapat dipahami bahwa persoalan keaksaraan ternyata tidak hanya terjadi di Indonesia, tapi juga menjadi permasalahan di beberapa negara, hal tersebut juga terjadi di Afrika sebagaimana yang dijelaskan dalam hasil penelitian Ambe J. Njoh and Fenda A. Kiwumi bahwa terbatasnya peran serta perempuan di sektor formal terkendala karena masih rendahnya tingkat melek huruf perempuan dan doktrin agama memiliki pengaruh terhadap ketidak berdayaan perempuan, ${ }^{4}$ padahal pemberdayaan perempuan hal penting untuk mendukung peran serta perempuan dalam proses pembangunan masyarakat.

Oleh karena itu dalam upaya pemberdayaan perempuan hal penting untuk dilakukan terlebih dahulu adalah memberantas keaksaraan dikalangan perempuan. Pemberdayaan merupakan upaya untuk melibatkan semua kemampuan agar dapat membuat pilihan sendiri, untuk mengembangkan strategi, dan mengubah ketidakseimbangan di dalam masyarakat. ${ }^{5}$ Pemberdayaan perempuan memiliki posisi urgen dalam pembangunan di dalam masyarakat. Karena selain untuk menggali potensi, pemberdayaan juga berfungsi untuk menumbuhkan sikap kritis, persepsi positif melalui kepedulian terhadap ketidakadilan struktural agar terjadi perubahan ke arah yang lebih baik. ${ }^{6}$

Untuk dapat melakukan semua peroses dan tujuan dari pemberdayaan perempuan tersebut terlebih dahulu perempuan harus bebas dari keaksaraan, kita tidak bisa berharap lebih dari semua keinginan untuk memberdayakan perempuan jika mereka memiliki masih terus dibiarkan dalam kondisi buta huruf, selain itu pemberdayaan perempuan harus mempertimbangkan beberapa hal diantaranya adalah: Pertama menciptakan suasana atau iklim yang kondusif yang memungkinkan untuk mengembangkan potensi perempuaan. Kedua memperkuat potensi (modal) sosial atau daya yang dimiliki perempuan utuk meningkatkan mutu hidupnya. Ketiga memberdayakan perempuan mengandung pengertian melindungi, yakni harus mencegah hal-hal 
yang mengandung penindasan, dan ketergantungan. ${ }^{7}$

Oleh karena itu membaca menjadi hal penting yang harus dilakukan oleh setiap manusia, agar bisa mengetahui dan memahami dirinya dan alam semesta di sekitarnya, namun tidak bisa dipungkiri bahwa sebagian besar masyarakat Indonesia yang belum bisa membaca didominasi oleh kaum perempuan, untuk memperkecil kesenjangan tersebut perlu dilakukan berbagai kegiatan yang membantu perempuan untuk terbebas dari keaksaraan. Jika selama ini Masjid difokuskan kepada berbagai kegiatan keagamaan, seperti baca yasin, belajar do'a, shalawatan, belajar zikir, tapi tidak kalah penting juga jika kegiatan keaksaraan dilakukan di Masjid.

Menjadikan masyarakat agar melek aksara bukan hal mudah, ada sejumlah faktor yang ada sebagi penghambat bahkan melekat di hati masyarakat, faktor apa yang menjadi kendala masih banyaknya perempuan yang mengalami buta huruf menjadi pertanyaan besar yang perlu diketahui akar persoalannya, padahal berbagai program pendidikan luar sekolah semakin galakkan dimana-mana, serta berbagai alternatif kegiatan dilakukan dengan berbagai metode yang dilakukan untuk memberantas keasaraan yang terjadi di
Indonesia, apakah program tersebut belum menyentuh komunitas perempuan, atau sudah dilakukan tapi belum maksimal dalam pelasanaannya, atau perempuan tidak mendapat dukungan dari pihak keluarga untuk ikut berpartisipasi dalam kegiatan pemberantasan keaksaraan terutama keaksaraan fungsional. Keaksaraan Fungsional berfungsi mengem- bangkan kemampuan dasar manusia yang meliputi kemampuan membaca, menulis dan berhitung yang bersifat fungsional dalam meningkatkan mutu dan taraf kehidupan dan masyarakatnya.

Berbagai pertanyaan tersebut membutuhkan jawaban dan solusi penyelesaiannya, karena jika hal ini dibiarkan berlarut-larut tidak hanya akan merugikan kaum perempuan saja, namun juga akan merugikan masyarakat, bangsa dan agama secara keseluruhan. Berbagai alternatif, motode dan juga pola pendekatan perlu terus dilakukan sehingga nantinya diharapkan dapat diketahui pola yang bagaimanakah yang akan membantu mempermudah proses pemberantasan keaksaraan di kalangan perempuan.

Sedangkan hubungannya dengan dakwah, dapat dilihat pada dakwah dalam dimensi kerahmatan yakni sebagai proses pengaplikasian nilai-nilai Islam baik dalam bentuk tadhbir maupun tathwir, ${ }^{8}$ memilki peran yang tidak kalah pentingnya 
terhadap upaya pemberdayaan perempuan. Jika dakwah dalam proses peyampaian pesan sudah cukup akrab dengan masyarakat, maka dakwah dalam konsep pemberdayaan juga perlu disosialisasikan lebih intens kepada masyarakat. Melalui kehadiran kelompok ataupun organisasi keagamaan perempuan, akan menjadi wadah perempuan untuk belajar, menggali bakat dan kemampuan yang dimilikinya, dengan bentuk kegiatan dakwah yang lebih konkret merespons kebutuhan dan permasalahan masyarakat terutama perempuan, akan menjadi alternatif dakwah yang tepat di era sekarang. ${ }^{9}$

Salah satu unsur penting dalam struktur masyarakat Islam adalah Masjid. Masjid memegang peranan penting dalam penyelenggaraan dakwah Islam, maka sangatlah wajar jika kata-kata masjid terulang sebanyak dua puluh delapan kali di dalam Al-Qur'an. Bila ditinjau dari segi bahasa, kata masjid terambil dari akar kata "sajada-sujud", yang berarti patuh, taat serta tunduk dengan penuh hormat dan takzim.1 Namun dalam arti terminologi, masjid diartikan sebagai tempat khusus untuk melakukan aktivitas ibadah dalam arti yang luas (universal). ${ }^{10}$

Masjid selain sebagai tempat ibadah umat Islam juga sebagai tempat pendidikan, menggerkan ekonomi umat bahkan pada masa Rasulullah Masjid menjadi tempat mengatur strategi perang. Melihat hal tersebut dapat kita ketahui bahwa Masjid memiliki fungsi penting bagi umat Islam, karena Masjid adalah pusat peradaban Islam. ${ }^{11}$ Oleh karena itu generasi terbaik dilahirkan di Masjid dan memiliki kedekatan dengan Masjid, dalam artian generasi yang rajin berjama'ah di Masjid, aktif dalam berbagai kegiatan yang diadakan di Masjid serta memiliki hubungan dekat dengan para pemuka agama/tokoh agama yang biasa memakmurkan Masjid memiliki hubungan terhadapan kehidupannya ke depan. Jadi pengembangan lembaga pendidikan Islam yang berbasis masyarakat yang dilakukan di Masjid-Masjid termasuk dari bagian kajian Program Studi Manajemen Dakwah, yakni bagaimana pengelolaan manajemen yang baik pada suatu lembaga pendidikan Islam yang dikelola oleh masyarakat.

Keaksaraan berbasis Masjid ditulis dalam Majalah Matan Edisi Januari 2012 yang ringkas dalam blog Benni Setiawan bahwa keaksaraan berbasis Masjid didasarkan pada realitas sosio-historis umat muslim. Membaca (iqra') merupakan perintah pertama Allah bagi umat Islam (Q.S. al-Alaq, 96: 1-5). Jadi membaca merupakan kewajiban alami manusia sebagai ciptaan Tuhan. Manusia akan mengetahui esensi penciptaan diri dan Tuhannya adalah melalui membaca. 
Dengan demikian membaca merupakan fitrah kemanusiaan yang utama. Dengan membaca manusia akan mempunyai cakrawala yang luas. Ia tidak mudah diperdaya oleh orang lain. Ia akan menjadi individu mandiri dan berkepribadian. Membaca juga menyegarkan pikiran. Membuat setiap kata yang terucap menjadi petuah bijak yang bermakna lagi bernilai. Pendek kata membaca akan mampu mengangkat derajat manusia ke taraf insan. $^{12}$

Mengingat hal tersebut, maka pemberdayaan perempuan melalui kegiatan keaksaraan berbasis Masjid menjadi penting untuk dicoba dilakukan, karena Masjid sebagai wadah bagi perempuan untuk melakukan banyak hal, mulai dari beribadah, bersosialisasi, belajar, dan menyalurkan potensi yang perempuan miliki, menjadi salah satu alternatif sebagai wadah yang tepat untuk mengadakan kegiatanan dalam rangka memberantas keaksaraan bagi kaum perempuan. Hal tersebut dengan beberapa pertimbangan diantaranya : yang mendatangi Masjid tidak dibatasi kelompok, golongan, atau pekerjaan tertentu saja, perempuan memilki kegiatan rutin pada hari jum'at melaksanakan shalat zuhur berjama'ah di Masjid, Jadi perempuan cukup memiliki komunitas tersendiri di Masjid.
Sama halnya dengan yang dilakukan oleh perempuan di Desa Renah Semanek, yang tidak bigitu disibukkan dengan anak yang masih kecil biasanya setiap hari jum'at mereka shalat berjamaah di Masjid, yang menjadi persoalan masih ada sebagian besar perempuan di Desa Rena Semanek tidak bisa membaca, baik membaca latin maupun membaca AlQuran, hal itu dikarenakan mereka tidak memiliki kesempatan mengenyam pendidikan. Namun mereka arata-rata bisa berhitung, terutama menghitung uang sebagai alat tukar di masyarakat.

Kaum perempuan belajar agama dan do'a dengan cara menghafal dan belajar dari mulut ke mulut, mereka bisa melafalkannya setelah mendengarnya dari guru namun mereka mengalami kesulitan ketika mendapat materi melalui tulisan. Hal ini cukup miris terjadi di kalangan perempuan sehingga membuat perempuan memiliki akses yang terbatas. Oleh karena itu menurut penulis penting untuk melakukan penelitian terkait dengan pemberantasan buta aksara perempuan berbasisi Masjid di Desa Renah Semanek.

Seperti penelitian yang telah dilakukan oleh beberapa akademisi terkait denganupaya pemberantasan buta aksara di kalangan masyarakat diantaranya adalah: Pertama penelitian yang telah dilakukan oleh Mariynono tentang strategi 
pemberantasan buta aksara yang dilakukan dengan melibatkan masyarakat setempat dan keluarga warga belajar dengan terlebih dahulu dilatih untuk menjadi tutor untuk mendidik keluarga mereka sendiri, sedangkan pendekatan yang dilakukan dengan menggunakan metode membelajarkan orang dewasa (andragogy). ${ }^{13}$ Menyiapkan tutor terlebih dahulu, yang nantinya akan membimbing masyarakat yang belum bisa membaca.

Selanjutnya Kedua Elais Retnowati yang mencoba untuk menganalisis hasil belajar keaksaraan fungsional yang dilakukan, dengan melihat kontribusi atau manfaat yang dirasakan yang dicapai setelah dilakukan program keaksaraan fungsional $^{14}$ bagi kehidupan peserta didik. ${ }^{15}$ Ketiga, Ima Ni'mah Chudari menjelaskan strategi pembelajaran yang tepat bagi warga belajar (WB), yaitu strategi pembelajaran yang integrative dan terpadu, yaitu antara proses pembelajaran membaca dengan pengembangan keterampilan, serta penanaman jiwa wiraswasta, akan memberikan semangat untuk mengembangkan potensi diri (SDM) dengan memanfaatkan sumberdaya alam yang ada disekitarnya. Disinilah hakekat dari pembelajaran yang memberdayaakan potensi WB yang ada untuk menuju masyarakat sejahtera, dengan mempertimbangkan waktu belajar, sistem tutorial dan memfasilitasi setelah melek aksara. $^{16}$

Sedangkan upaya pemberantasan buta aksara yang bisa dilakukan di Desa Renah Semanek adalah berawal dari Masjid, hal ini lebih muda dilakukan karena kaum ibu setiap hari jum'at biasanya shalat zuhur berjamaah di Masjid setelah para laki-laki selesai melaksanakan shalat jum'at. Mengingat hal tersebut secara otomatis kaum perempun sudah berkumpul di Masjid tanpa perlu diundang, sehingga Masjid menjadi basis kegiatan keaksaraan.

\section{PENUTUP}

Berbagai alternatif pemberantasan buta aksara di kalangan perempuan perlu terus dicoba, untuk meminimalisir banyaknya buta huruf dikalangan masyarakat Indonesia. Berbagai upaya yang telah dilakukan oleh pemerintah namun tidak bisa dipungkiri masih ada beberapa ditemui masyarakat yang mengalami buta huruf. Pemberantasan buta aksara bagi kaum perempuan dengan fokus kegiatan di Masjid perlu dilakukan mengingat Masjid menjadi pusat-pusat pendidikan masyarakat yang menyetuh langsung masyarakat diseluruh lapisan dengan beragam latar belakan pendidikan dan profesi. Sedangkan jadwal kegiatan rutin, yang sudah dilakukan pertemuan 
setiap satu kali dalam satu minggu, dengan jumlah jamaah tetap yang sudah pasti. Oleh karena, Masjid menjadi salah satu alternatif bagi perempuan Muslim yang

\section{Endnote}

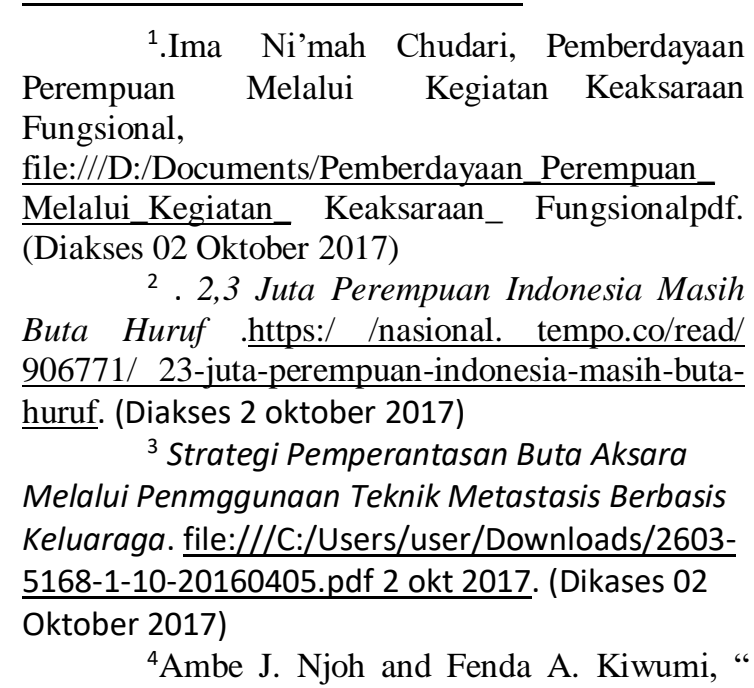
The Impact of Religion on Women Empowerment as a Millennium Development Goal in Africa", Journal of Social indicators 107 (2012).1-18. http://link.springer.com, (Diakses 3 februari 2014).

${ }^{5}$ Brenda Bartelink and Marjo Buitelaar, "The Challenges of Incorporating Muslim Women's Views into Development Policy: Analysis of a Dutch Action Research Project in Yamen", Gender and Developmet 14 (2006), 351$362 . \quad$ http://www.jstor.org/stable/20461158. (Accessed: 16/03/2014).

${ }^{6}$ Mari-Pier Rivest and Nicolas Moreau, "Between Emancipatory Practice and Disciplinary Interventions: Empowerment and Contemporary Social Normativity"British Journal of Social Work (2014) 1-16. http://bjsw.oxfordjournals.org. (Diakses 13 Mei, 2014).

${ }^{7}$ Roosganda Elizabeth,"Pemberdayaan Wanita Mendukung Strategi Gender Mainstreaming dalam Kebijakan Pembangunan Pertanian di Pedesaan" Forum Penelitian Agro Ekonomi 25 (2007), 126-135. http://pse.litbang.pertanian.go.id/ind/pdffiles/FAE2 5-2e.pdf. (Diakses 3 Februari, 2015).

8 Aep Kusnawan, " Arti dan Dimensi Dakwah" dalam Aep Kusnawan dkk, Dimensi Ilmu Dakwah, Tinjauan Dakwah dari Aspek Ontologi, Epistemologi, Aksiologi, hingga Paradigma Pengembangan Profesionalisme, (Bandung : Widya Pedjadjaran, 2009), 17- 25.

$$
\text { 9. Rodiyah, Strategi Dakwah }
$$

Pemberdayaan Perempuan, Jurnal Syiar, V01 2 Edisi Juli-Desember Tahun 2015. masih mengalami buta aksara sebagai salah satu wadah untuk menghapuskan keaksaraan di kalangan perempuan.

${ }^{10}$ Miftah Farid, Masjid, (Bandung:

Pustaka, 1984) h. 1

11 Taufiqurrahman, "Pendidikan

Masyarakat Berbasis Masjid",

http://repository.uin-

malang.ac.id/799/2/masjid.pdf(diakses Kamis, 27 April 2015).

12 Keaksaraan Berbasis Masjid, http://bennisetiawan.blogspot.co.id/2012/01/keaksa raan-berbasis-masjid.html

${ }^{13}$ Mariyono, Strategi Pemberantasan Buta Aksara Melalui Penggunaan Teknik Metastesis Berbasisi Keluarga,

${ }^{14}$.. Direktorat Pendidika Masyarakat, Pedoman SertifikasiPendidikan Keaksaraan (Jakarta: Departemen Pendidikan Nasional, 2004)

15 Elais Retnowati, "Analisis

Fungsionalisasi Hasil Belajar Warga Belajar Keaksaraan di Kecamatan Sukamakmur Kabupaten Bogor", Jurnal Ilmiah Visi PPTK PAUDNI, Vol 1 No 1 Juni 2015. file://C:/Users/user/Downloads/3743-769-6400-110-20170905.pdf. (Diakses 02 Oktober 2017).

16. Ima Ni'mah Chudari, Pemberdayaan Perempuan Melalui Kegiatan Keaksaraan Fungsional, file:///D:/Documents/ Pemberdayaan Perempuan Melalui Kegiatan Keaksaraan Fungsional (Diakses 02 Oktober 2017) 